OPEN ACCESS

Edited by:

Fatma Mohamady El-Demerdash, Alexandria University, Egypt

*Correspondence: Jae-Ho Oh mfdsnc@korea.kr Jong Kwon Lee jkleest@korea.kr

Specialty section: This article was submitted to

Predictive Toxicology,

a section of the journal Frontiers in Pharmacology

Received: 22 February 2021

Accepted: 11 March 2021

Published: 14 April 2021

Citation:

Kim S-H, Lee $J H$, Jung $K$, Yang J-Y, Shin H-S, Lee JP, Jeong J, Oh J-H and Lee JK (2021) Corrigendum: Copper and Cobalt lons Released From Metal

Oxide Nanoparticles Trigger Skin Sensitization.

Front. Pharmacol. 12:670581. doi: 10.3389/fphar.2021.670581

\section{Corrigendum: Copper and Cobalt lons Released From Metal Oxide Nanoparticles Trigger Skin Sensitization}

\author{
Sung-Hyun Kim, Jin Hee Lee, Kikyung Jung, Jun-Young Yang, Hyo-Sook Shin, \\ Jeong Pyo Lee, Jayoung Jeong, Jae-Ho Oh* and Jong Kwon Lee* \\ Division of Toxicological Research, National Institute of Food and Drug Safety Evaluation, Ministry of Food and Drug Safety, \\ Osong, South Korea
}

Keywords: skin sensitization, alternative test, KeratinoSens TM, LLNA, dissolving nanoparticles, nanoparticles, copper, cobalt

\section{A Corrigendum on}

Copper and Cobalt ions Released from Metal Oxide Nanoparticles Trigger Skin Sensitization by Kim S-H, Lee JH, Jung K, Yang J-Y, Shin H-S, Lee JP, Jeong J, Oh J-H and Lee JK (2021). Front. Pharmacol. 12:627781. doi: 10.3389/fphar.2021.627781

In the original article, there was an error. The value $0.00 \mu \mathrm{M}$ was mistakenly inserted instead of $316.57 \mu \mathrm{M}$.

A correction has been made to Results, Evaluation of NPs-Induced Sensitization in the KeratinoSens $^{\mathrm{TM}}$ Assay, Paragraph 1:

"The five metal oxide NPs were assessed for their skin sensitization potential using the KeratinoSens $^{\mathrm{TM}}$ assay; the data are shown in Table 2 and Figure 2. $\mathrm{CuO}$ and $\mathrm{CoO}$ NPsinduced activity of the luciferase reporter by over 1.5 -fold, suggesting their ability to cause skin sensitization. The other NPs did not increase luciferase activity in the KeratinoSens ${ }^{\mathrm{TM}}$ assay. The $\mathrm{EC}_{1.5}$ value for $\mathrm{CuO}$ and $\mathrm{CoO}$ NPs was 1.38 and $316.57 \mu \mathrm{M}$ respectively, classifying them as sensitizers, whereas the values were $>1,000 \mu \mathrm{M}$ for the remaining NPs, classifying them as non-sensitizers."

The authors apologize for this error and state that this does not change the scientific conclusions of the article in any way. The original article has been updated.

Copyright $\odot 2021$ Kim, Lee, Jung, Yang, Shin, Lee, Jeong, Oh and Lee. This is an open-access article distributed under the terms of the Creative Commons Attribution License (CC BY). The use, distribution or reproduction in other forums is permitted, provided the original author(s) and the copyright owner(s) are credited and that the original publication in this journal is cited, in accordance with accepted academic practice. No use, distribution or reproduction is permitted which does not comply with these terms. 